UNITED STATES DEPARTMENT OF THE INTERIOR

\author{
GEOLOG ICAL SURVEY
}

Digital shipboard gravity and magnetic data collected
in 1982 on the Bering Sea shelf

by

1

1

1

Alan K. Cooper, Michael S. Marlow, and Jon R. Childs

Open-File Report $85-236$

This report is preliminary and has not been reviewed for conformity with U.S. Geological Survey editorial standards and stratigraphic nomenclature.

Any use of trade names is for descriptive purposes only and does not constitute endorsement by the U.S. Geological Survey.

1 .

345 Middlefield Road, MS 99

Menlo Park, California 94025 
During 1982, the U.S. Geological Survey collected about $5000 \mathrm{~km}$ of digital gravity and magnetic data across the Bering Sea shelf (St. George and Bristol Bay and Navarin basins, Figs. 1 and 2) aboard the USGS research vessel S.P. LEE (cruise L9-82-BS). Preliminary results of the cruise are described by Cooper and Marlow (1983). Other magnetic traverses of the area (Cooper et al., 1985), a magnetic map of the adjoining Umak Plateau region (Childs et al., 1981) and gravity maps of the Bering sea (Childs et a l, $1985 a, b, c)$ are also available.

MAGNETIC DATA

Total field magnetic data were sampled with a Geometrics proton precession magnetometer and recorded every 4 seconds. The magnetometer was towed 183 meters behind the ship at a depth of between 18 and 31 meters. Reduction of the magnetic data included removal of the 1975 IGRF regional field (IAGA,1976), corrected to 1982 , to obtain a total field anomaly. The location of each magnetic reading is not corrected for the 183 meter tow distance of the magnetometer behind the ship. Temporal magnetic variatione iave not been removed from the data.

\section{GRAVITY DATA}

Shipboard gravity data were recorded at 20 second intervals with a 2-axis, stable-platform, LaCoste-Romberg seagravimeter (meter s-53). Eotvos corrections, based on the final smoothed navigation, and adjustments for the 1967 reference ellipsoid (International Association of Geodesy, 1971) were applied to the field data to obtain free-air anomalies. A correction for gravity meter drift was also applied using base-station ties at the start (Dutch Harbor, $A K$ ) and end (Nome, $A K$ ) of the cruise.

\section{NAVIGATION DATA}

Navigational control of the survey was by satellite fixes integrated with Loran C (Rho-Rho) and doppler-sonar bottomtrack navigation. Course and speed values between navigational fixes were subsequently smoothed for the gravity data to remove large changes in eotvos corrections.

DIGITAL DATA

In the final stage of the data reduction, the gravity and magnetic data were merged with the navigation data at 1 minute intervals and stored on magnetic tape. The information contained on the tape includes: 
Year

Julian Day

Hour

Minute
Observed gravity

Theoretical gravity

Eotvos correction

Free-air anomaly
Observed magnetics IGRF regional field Total field anomaly Latitude/Longitude

Copies of the data are available through the National Geophysical Data Center, NOAA/EDIS/NGDC, Code D64, 325 Broadway, Boulder, Co 80303. Telephone (303) 497-6338.

\section{REFERENCES}

Childs, J.R., Cooper, A.K., and A.W. Wright, 1981 , Residual magnetic map of Umnak Plateau region, southeastern Bering Sea: U.S. Geol. Survey map GP-939.

Childs, J.R., Magistrale, H.W., and A.K. Cooper, 1985 a, Free-air gravity map of the Bering Sea, U.S. Geol. Survey MF map 1728 .

Childs, J.R., Magistrale, H.W., and A.K. Cooper, $1985 \mathrm{~b}$, Free-air gravity map of the Umnak Plateau region, southeastern Bering Sea, U.S. Geol. Survey GP map 970 .

Childs, J.R., Magistrale, H.W., and A.K. Cooper, $1985 \mathrm{c}$, Free- air gravity map of the central and northern Bering Sea, U.S. Geol. Survey GP map 971 .

Cooper, A.K., and M.S. Marlow, 1983, Geologic and geophysical studies of the inner Bering Sea shelf during 1982: U.S. Geol. Survey in Alaska: accomplishments in 1982 , U.S. Geol. Survey circular 939 , p. 123-126.

Cooper, A.K., Marlow, M.S., and J.R. Childs, 1985 , Digital shipboard gravity and magnetic data collected in 1976 in the southern Bering Sea: U.S. Geol. Survey open-file report, 2 p., in press.

IAGA Division 1 Study Group, 1976, International geomagnetic reference field: EOS, Transactions American Geophysical Union, v. 57, n. 3, p. 120-121.

International Association of Geodesy, 1971, Geodetic reference system, 1967,: Paris Bureau Central de l'Association Internationale de Geodesie Special Publication $3,116 \mathrm{p}$. 


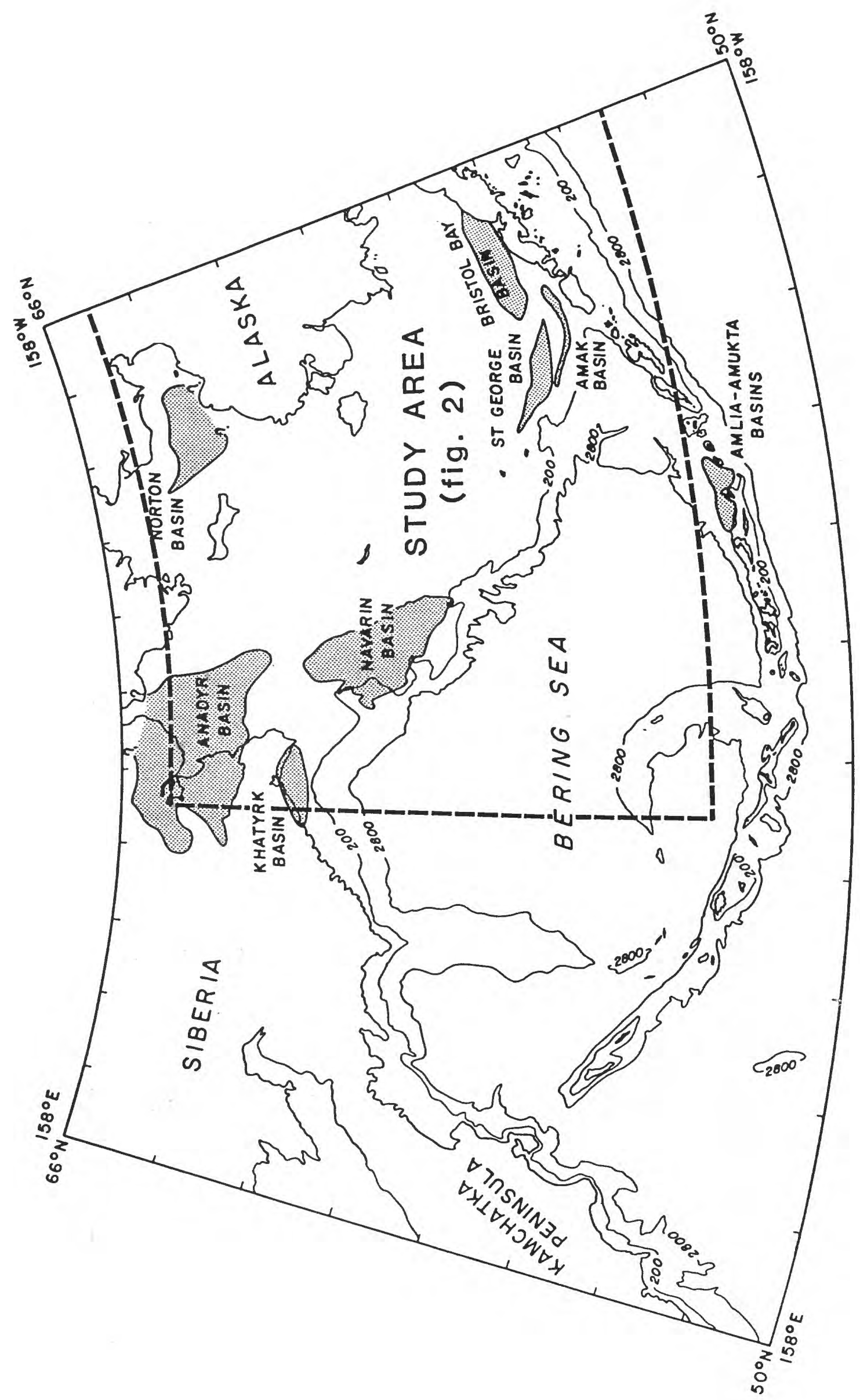

Figure 1: Index map of the Bering sea showing location of trackline map in figure 2 . 


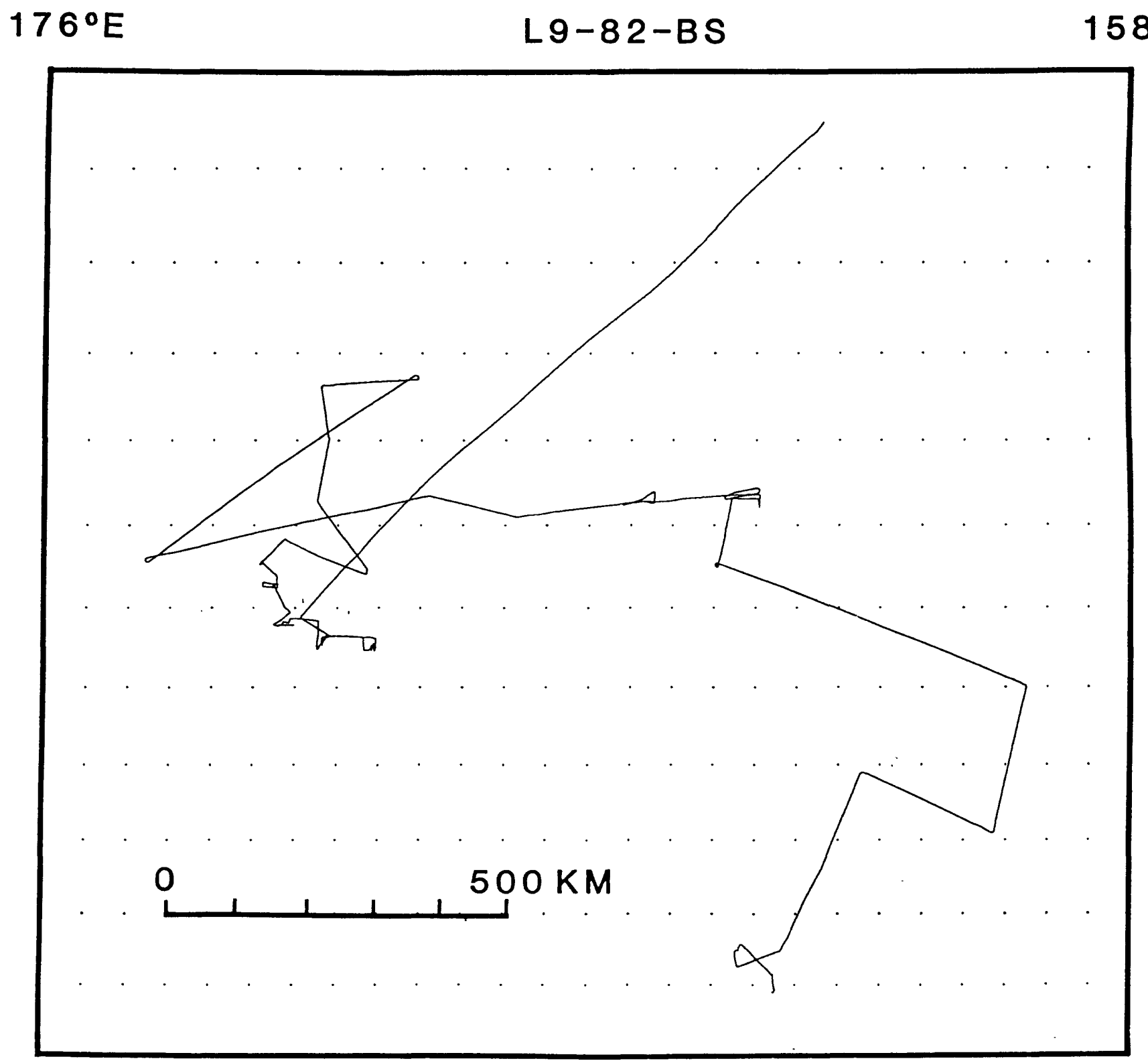

Figure 2: Map showing location of ship tracklines for USGS cruise L9-82-BS. Gravity and magnetic data were collected along most, but not all segments of these tracklines. See figure 1 for location. 